\title{
Effect of Glycemic Control on Adipokines in Diabetic Patients with Pulmonary Hypertension
}

\author{
MANAR M. EL-ZAKI, M.D.*; NADER KANDIL, M.D.*; SAMIA HUSSEIN, M.D.**; \\ MAI M. HASAN, M.D.*** and ABEER A. SAEED, M.D.*** \\ The Departments of Cardiology*, Medical Biochemistry \& Molecular Biology** and Medical Physiology***, \\ Faculty of Medicine, Zagazig University, Egypt
}

\begin{abstract}
Background: Recent studies suggested a role of diabetes in regulating the outcome of pulmonary hypertension. Several cytokines are dysregulated in pulmonary hypertension, and were considered accurate predictors of the prognosis.

Aim of Study: To evaluate the effects of glycemic control on hemodynamics, metabolic and adipokines (leptin, apelin and adiponectin) levels in patients with pulmonary hypertension and diabetes.

Subjects and Methods: Thirty-five pulmonary hypertension patients with diabetes assigned into two groups according to glycosylated hemoglobin (HbA1c) level; tightly controlled group (Group I) ( $\mathrm{n}=20)$ and conventionally controlled group (Group II) $(n=15)$. Demographic characteristics, hemodynamic assessment, metabolic and serum adipokines levels were assesed.

Results: Both groups showed insignificant difference in age, BMI and left ventricular ejection fraction; while mean pulmonary arterial pressure, HbA1c, fasting blood glucose, insulin, HOMA-IR, Cholesterol, triglycerides, Interleukin-6, leptin and apelin were significantly decreased in group I. IL6 , leptin and apelin have significant positive correlation with glucose, insulin, HOMA-IR, Cholesterol, TG and MPAP in both groups.

Conclusion: Good glycemic control has an impact on hemodynamics, metabolic, inflammatory and adipokine pattern in diabetic patients with pulmonary hypertension, which may affect the progression of the disease.
\end{abstract}

Key Words: Diabetes - Leptin-Apelin-Adiponectin - IL6 - Pulmonary hypertension.

\section{Introduction}

DIABETES is the main fourth cause of death from non-communicable diseases [1]. It results in systemic macro- and microvascular dysfunction, and multiple mechanisms explain the well-defined, coincident endothelial dysfunction [2] .

Correspondence to: Dr. Mai M. Hasan,

E-Mail: mmjewefel@gmail.com
Pulmonary arterial hypertension (PAH) was previously considered an isolated disease of pulmonary circulation; now, it is linked to insulin resistance and metabolic dysfunction [3] with many factors contributing to its occurrence and progression [4]

Endothelial cells from pulmonary arteries in pulmonary hypertension secrete leptin and their regulatory T-cells have increased leptin receptor [я. In addition, vascular inflammation is associated with development of pulmonary hypertension. Moreover, adiponectin suppresses vascular inflammation [6] and adiponectin deficiency affect the development of pulmonary hypertension with a role linked to vascular inflammation and pulmonary artery remodeling $[6,7]$.

Apelin is expressed in the lungs, especially in pulmonary vasculature [8] while IL-6 is produced by several cells [9]

Moreover, intensive diabetes control could decrease microvascular complications of diabetes $[10,11]$

Although, previous studies showed that diabetic patients have an increased risk for developing $\mathrm{PH}$ independent of other risk factors; yet, fewer reports if any, reported the effect of glycemic control on metabolic, adipokine and hemodynamic pattern in diabetic patients with pulmonary hypertension.

\section{Patients and Methods}

The study included 35 subjects. The study was conducted in Echocardiographic Unit (Zagazig University Hospital) Cardiology Department, Medical Biochemistry and Molecular Biology Department and Medical Physiology Department, Faculty of Medicine, Zagazig University between August 
2015 and September 2016. All patients gave adequate informed consent. They were classified into two groups:

Group I (with HbAl c <6\%): Included 20 male patients, considered as tightly glycemic controlled

Group II (with $\mathrm{HbAl} c \geq 6 \%$ ): Included 15 patients (10 male, 5 females) considered as conventionally glycemic uncontrolled [11].

All patients were subjected to detailed history taking, examination, standard ECG and conventional Echocardiography: A complete M-mode, two-dimensional and pulsed Doppler echocardiography was performed in each patient. The left ventricular ejection fraction (EF) was calculated using the biplane modified Simpson's method in the four and two chamber apical views. The RV systolic function was measured by the fractional area change (RVFAC in the apical 4-chamber view.

Where the normal values for RVFAC according to the American society of echocardiography guide lines for chamber quantification ranges from 3563. Tricuspid annular plane systolic excursion (TAPSE) as a parameter for RV long axis function was assessed with M-Mode cursor positioned at the free wall angle of the tricuspid valve annulus (J. Am. Soc. Echocardiography (2010).

Patients with $\mathrm{PH}$ proved by echocardiography then calculating mean pulmonary artery pressure.

Biochemical measurements: Venous blood samples were collected from all cases and centrifuged at 3,000 r.p.m. for 10 minutes, serum samples were stored at $-70^{\circ} \mathrm{C}$ until analyzed for: Fasting glucose, insulin, cholesterol, triglycerides, HDL, IL-6, Leptin, adiponectin and Apelin. HOMA IR was calculated by the equation:

HOMA-IR = Fasting blood glucose in $\mathrm{mg} / \mathrm{dl} \mathrm{x}$ fasting insulin $/ \mathbf{l} / \mathbf{L} / 405$ [12]

Statistical analysis: Quantitative variables were presented as mean (standard deviation; qualitative variables as numbers and percentages. Quantitative variables were tested by Student $t$-test. Relationships were assessed using Pearson correlation coefficient; $p$-value $<0.05$ was considered significant. Analysis of the results was performed using the Statistical Package for the Social Sciences (SPSS), version 19.0 (SPSS Inc., Chicago, IL, United States).

\section{Results}

Demographic and metabolic data of the studied groups showed insignificant difference in age and BMI. Group II had significantly higher FBG, insu- lin, HOMA-IR, cholesterol, triglycerides and $\mathrm{HbA} 1 \mathrm{c} \%$ than group I (Table 1).

Adipokine levels were significantly different between the studied groups (Table 2); Group II showed significantly higher IL-6, Leptin and Apelin associated with lower Adiponectin compared to group I.

Hemodynamic data from the studied groups revealed no significant difference between groups in LVEF\%; while TAPSE, RVFAC, RVS were significantly lower in group II whose MPAP were higher than group I (Table 3).

Apart from significant negative correlation with HDL, significantly positive correlation between serum IL-6 and FBG, HOMA-IR, cholesterol, triglycerides and $\mathrm{HbA} 1 \mathrm{c} \%$ was reported. Also, Leptin and apelin had the same correlation; in addition to significant positive correlation with insulin and $\mathrm{HbA} 1 \mathrm{c} \%$. Adiponectin showed significant negative correlation to all metabolic and serum parameters except HDL (Table 4).

Serum adipokines (IL-6, Leptin, and Apelin) were positively correlated to MPAP in the studied groups; while adiponectin showed negative correlation (Fig. 1).

Table (1): Shows comparison of demographic and metabolic data of the studied groups.

\begin{tabular}{|c|c|c|}
\hline & $\underset{(n=20)}{\text { Group I }}$ & $\underset{(\mathrm{n}=15)}{\text { Group II }}$ \\
\hline Age (years) & $53.8 \pm 4.4$ & $52.3 \pm 1.8$ \\
\hline \multicolumn{3}{|l|}{ Sex: } \\
\hline Male & $20(100 \%)$ & $10(66.7 \%)$ \\
\hline Female & $0(0 \%)$ & $5(33.3 \%)$ \\
\hline $\operatorname{BMI}\left(\mathrm{Kg} / \mathrm{m}^{2}\right)$ & $22.6 \pm 1.3$ & $21.9 \pm 1.7$ \\
\hline FBG (mg/dL) & $109.5 \pm 16.3$ & $194 \pm 50.1 *$ \\
\hline Insulin ( IU/ml) & $6.6 \pm 0.6$ & $10.5 \pm 1.9 *$ \\
\hline HOMA-IR & $1.8 \pm 0.1$ & $4.9 \pm 0.4^{*}$ \\
\hline Cholesterol (mg/dL) & $218.7 \pm 10.6$ & $296.8 \pm 13.9 *$ \\
\hline Triglycerides (mg/dL) & $88.6 \pm 13.8$ & $111.1 \pm 6.8 *$ \\
\hline HDL (mg/dL) & $35.7 \pm 8.3$ & $32.2 \pm 4.4$ \\
\hline $\mathrm{HbA} 1 \mathrm{c} \%$ & $5.2 \pm 0.5$ & $7.7 \pm 0.1 *$ \\
\hline \multicolumn{3}{|c|}{$\begin{array}{l}\text { BMI } \\
\text { HOMA-IR. : : Hody mass index. } \\
\text { HDL } \quad: \text { High density lipoproteins. } \\
\text { HbA1c } \quad: \text { Glycated hemoglobin. } \\
{ }^{*} p<0.001 \text { using student } t \text {-test. }\end{array}$} \\
\hline \multicolumn{3}{|c|}{$\begin{array}{l}\text { Table (2): Shows comparison of adipokine pattern of the } \\
\text { studied groups. }\end{array}$} \\
\hline & $\begin{array}{l}\text { Group I } \\
(n=20)\end{array}$ & $\underset{(n=15)}{\text { Group II }}$ \\
\hline IL-6 (pg/ml) & $126.3 \pm 15.5$ & $166.6 \pm 39.8 *$ \\
\hline Leptin (ng/ml) & $9.6 \pm 3.1$ & $14.2 \pm 1.4^{*}$ \\
\hline Adiponectin (ng/ml) & $5.9 \pm 1.9$ & $2.98 \pm 0.9 *$ \\
\hline Apelin ( $\mathrm{g} / \mathrm{hl})$ & $11.7 \pm 2.2$ & $18.7 \pm 1.2 *$ \\
\hline
\end{tabular}


Table (3): Shows Comparison of hemodynamic data of the studied groups.

\begin{tabular}{lcc}
\hline & $\begin{array}{c}\text { Group I } \\
(\mathrm{n}=20)\end{array}$ & $\begin{array}{c}\text { Group II } \\
(\mathrm{n}=15)\end{array}$ \\
\hline LVEF \% & $53.3 \pm 2.9$ & $52.7 \pm 2.1$ \\
TAPSE (mm) & $17.9 \pm 0.7$ & $15.9 \pm 0.6^{*}$ \\
RVFAC \% & $38.8 \pm 0.7$ & $36.4 \pm 0.6^{*}$ \\
RVS' $^{\prime}(\mathrm{cm} / \mathrm{s})$ & $10.5 \pm 0.3$ & $9.9 \pm 0.2^{*}$ \\
MPAP $(\mathrm{mmHg})$ & $29.5 \pm 4.3$ & $59.7 \pm 5.4^{*}$ \\
\hline
\end{tabular}

LVEF : Left ventricular ejection fraction.

TAPSE : Tricuspid annular plane systolic excursion.

RVFAC: Right ventricular fractional area change.

RVS' : Right ventricular systolic wave.

MPAP : Mean pulmonary arterial pressure.

${ }^{*} p<0.001$ using student $t$-test.
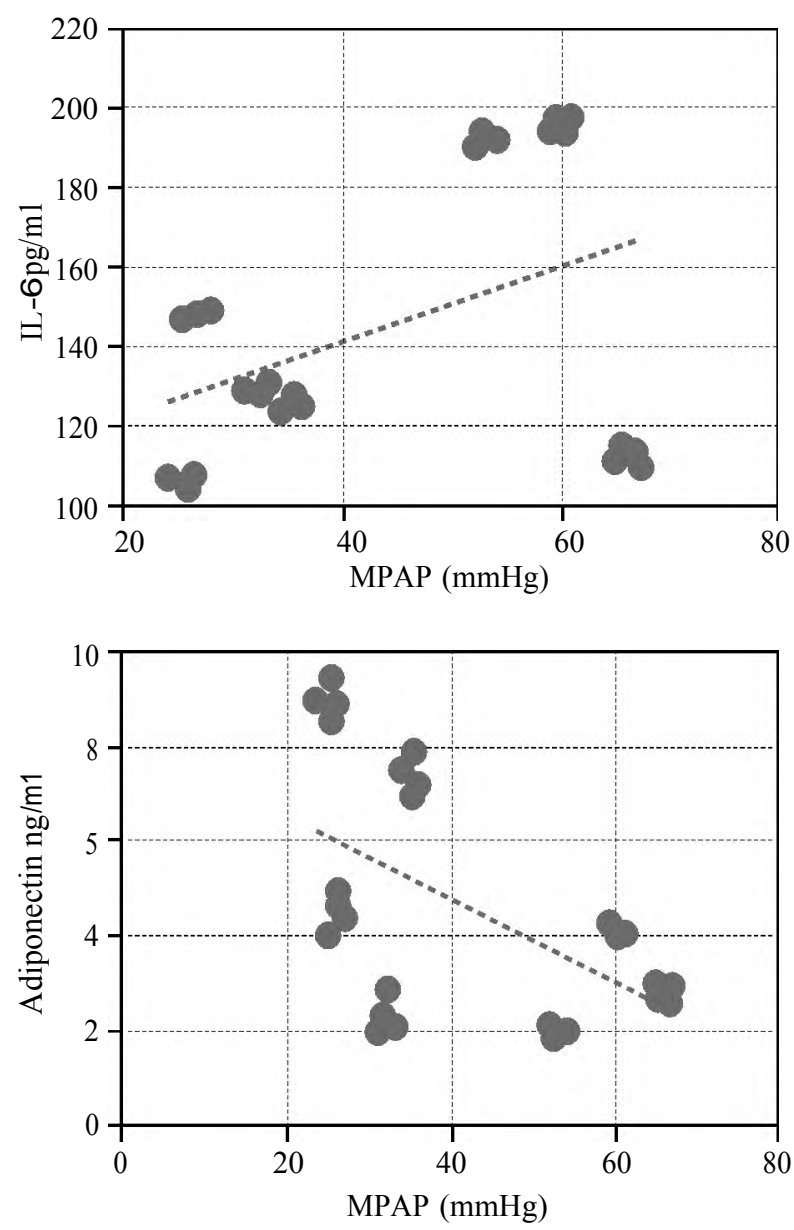

Table (4): Shows Pearson correlations between serum IL-6, leptin adiponectin and Apelin in the studied groups and metabolic parameters.

\begin{tabular}{lllll}
\hline & \multicolumn{1}{c}{ IL-6 } & Leptin & $\begin{array}{c}\text { Adipo- } \\
\text { nectin }\end{array}$ & Apelin \\
\hline FBG & $0.660 * * *$ & $0.457 * *$ & $-0.385 *$ & $0.731 * * *$ \\
Insulin & $0.295 \mathrm{NS}$ & $0.627 * * *$ & $-0.508 * *$ & $0.781 * * *$ \\
HOMA-IR & $0.555^{* * *}$ & $0.667 * * *$ & $-0.551 * *$ & $0.905 * * *$ \\
Cholesterol & $0.623 * * *$ & $0.794 * * *$ & $-0.606 * * *$ & $0.883 * * *$ \\
Triglycerides & $0.395 *$ & $0.825 * * *$ & $-0.486 * *$ & $0.587 * * *$ \\
HDL & $-0.182 \mathrm{NS}$ & $-0.799 * * *$ & $0.656 * * *$ & $-0.374 *$ \\
HbA1c $\%$ & $0.466 * *$ & $0.535 * * *$ & $-0.475 * *$ & $0.873 * * *$ \\
\hline
\end{tabular}

${ }^{*} p<0.05 .{ }^{* *} p<0.01 .{ }^{* * *} p<0.001$ and NS $p>0.05$ using student $t$-test.
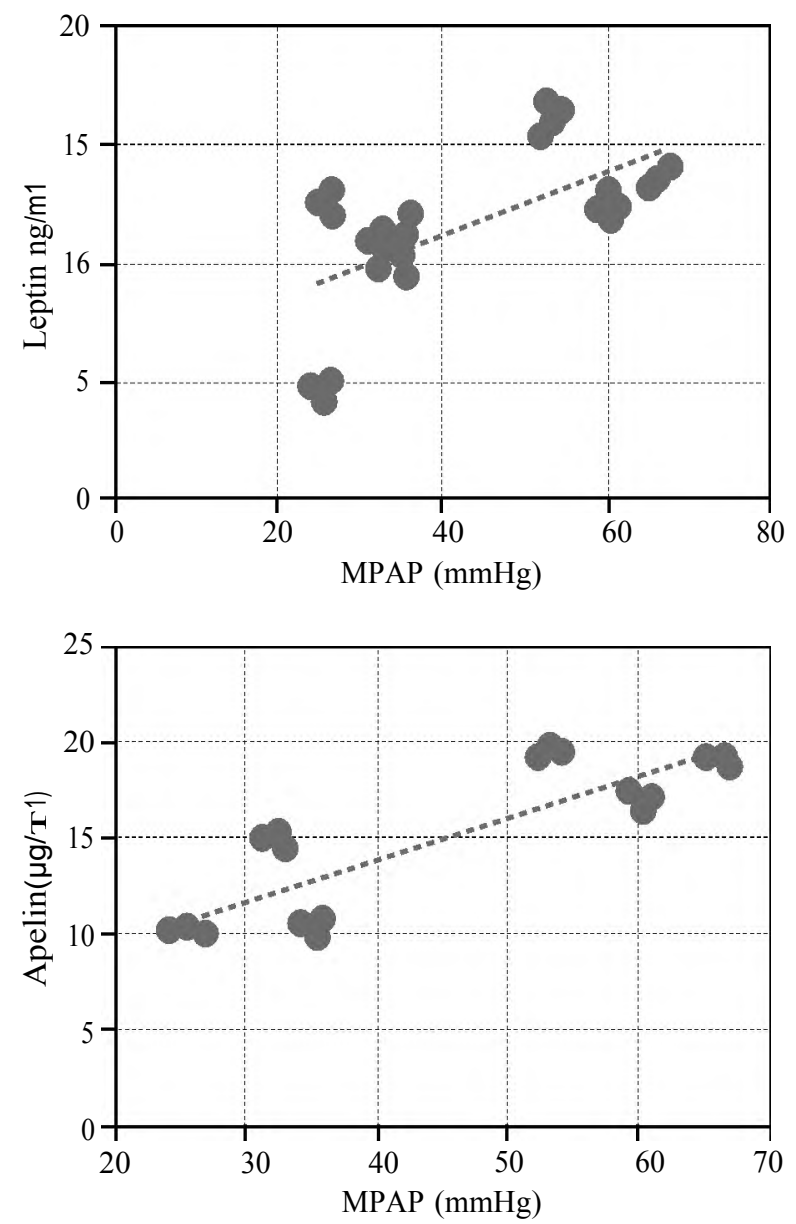

Fig. (1): Shows Pearson correlations between MPAP and serum IL-6, leptin adiponectin and Apelin in the studied groups.

\section{Discussion}

The results of the present study showed that metabolic parameters namely FBG, insulin, HOMA-IR, cholesterol and triglycerides, were significantly higher in conventionally controlled than tightly controlled diabetics; dyslipidemia was found to be more severe with increased levels of $\mathrm{HbA} 1 \mathrm{c}$ \%, [13] . Annadurai et al., [14] reported higher FBG, cholesterol and triglycerides in diabetic group who have higher $\mathrm{HbA} 1 \mathrm{c} \%$ and suggested useful roles of $\mathrm{HbA} 1 \mathrm{c} \%$ not only indicating long-term glycemic control but also, the onset of complications at clinical and molecular levels.

Arterial remodeling, vascular smooth muscle cells proliferation and migration and altered activity could result from hyperglycemia [15]; also, ad- 
vanced glycation end products (AGEs) block nitric oxide (NO) activity in the endothelium [16]

Moreover, insulin resistance and dysregulated glucose metabolism act as disease modifier of pulmonary hypertension owing to enhancement of inflammatory processes, deregulation of the NO pathway and endothelial damage [17]. In animal models of insulin resistance, the animals developed pulmonary hypertension suggesting the promoting role of insulin resistance in pulmonary vascular disease [3]

The result of the present study showed significantly higher IL-6 levels in conventionally than tightly controlled PH patients. Jayashree et al. [18] found that serum IL-6 levels were significantly increased in diabetic patients compared to control; over-production of IL-6 was largely restored after proper glycemic control [19]. Insulin resistance itself has an inflammatory action; levels of IL-6 have been shown to increase with diabetes [20]

Moreover, studies reported that IL-6 is implicated in the pathogenesis of $\mathrm{PH}$; serum levels of IL-6 are elevated in patients with PH [21] and higher levels of IL-6 are associated with poor prognosis of those patients [22]. In line with the results in this study, pulmonary hypertension patients who had higher levels of IL-6 had significantly worse right ventricular function (FAC, TAPSE) [21]

This study showed that, serum leptin and apelin levels were significantly higher in conventionally controlled than tightly controlled diabetic $\mathrm{PH}$ patients. Improved glycemic control decreases plasma leptin levels, was also demonstrated [23] Pulmonary hypertension patients had increased serum leptin levels compared to controls, with much of leptin secretion originating from pulmonary endothelial cells [5]. Abnormal over activation of leptin/leptin receptor axis in pulmonary vascular wall, contributes to susceptibility and progression of pulmonary hypertension [24] as leptin contributes to systemic vascular remodeling acting as a proliferative and migratory factor for vascular SMCs, and as a potent immunomodulator for vascular wall inflammatory cell infiltration [25]

Apelin levels were found to be increased in diabetic subjects compared with the controls and plasma apelin levels correlated positively with HOMA-IR, BMI, TC, LDL-C, FBG and plasma insulin [26]

A positive correlation between plasma apelin concentrations and $\mathrm{HbA} 1 \mathrm{c}$ was described [27]
Although previous studies demonstrated decreased serum apelin levels in pulmonary hypertension patients [28] and the benefits of augmented apelin signaling in ameliorating symptoms of pulmonary hypertension in rodent models [29], yet in this study, patients exhibit insulin resistance which accompanies increased plasma apelin levels [30] High apelin levels observed in insulin-resistance, could suggest a compensatory mechanism to reduce insulin resistance and to improve impaired secretion [31] and the link between dysfunctional pulmonary endothelial cells and apelin-APJ axis in these cells may be implicated in the pathogenesis of $\mathrm{PH}$ [32]

Regarding adiponectin, an adipokine with known insulin-sensitizing, anti-inflammatory, and antiproliferative properties, this study revealed significant decrease in adiponectin levels in conventionally than tightly controlled $\mathrm{PH}$ patients.

Poorly controlled diabetic patients showed significant deregulation of adiponectin and this was reversed by improved glycemic control [33] An inverse correlation between adiponectin and insulin resistance was also demonstrated [34]. Moreover, adiponectin levels were shown to be inversely proportionate to the degree of pulmonary hypertension [35].

In line with the current study, adiponectin is associated positively with HDL-C and negatively with HbAlc [36]

The results of the current study revealed significantly worse hemodynamic parameters (TAPSE, RVFAC, RVSW and MPAP) in conventionally controlled (Higher HbA1c) than those of tightly controlled (lower HbA1 c) PH patients. A relationship was confirmed between HbAlc and hemodynamic parameters in pulmonary hypertension patients [37]. Also, at the time a patient is diagnosed with $\mathrm{PH}, \mathrm{HbA} 1 \mathrm{c}$ was an independent predictor of survival [38]. The right ventricle is adversely impacted by diabetes in patients with Pulmonary hypertension, hyperglycemia and insulin resistance [39].

Collectively, the present study illustrates the favorable impact of good glycemic control on metabolic, hormonal and hemodynamic patterns in pulmonary hypertensive diabetic patients which suggests a role in the outcome of the disease. Limitations of this study are that it is performed on small number of patients in one centre and, it was cross-sectional approach without long followup period. 


\section{References}

1- World Health Statistics: Monitoring health for the SDGs, Sustainable Development Goals. Geneva: World Health Organization. Licence, CC BY-NC-SA 3.0 IGO, 2017.

2- BROWNLEE M.: Biochemistry and molecular cell biology of diabetic complications. Nature, 414 (6865): 813-820, 2001.

3- ASSAD T.R. and HEMNES A.R.: Metabolic Dysfunction in Pulmonary Arterial Hypertension. Curr. Hypertens. Rep., 17 (3): 20, 2015.

4- ROSS D.J., HOUGH, HAMA S., ABOULHOSN J., BELPERIO J.A., SAGGAR R., et al.: Proinflammatory highdensity lipoprotein results from oxidized lipid mediators in the pathogenesis of both idiopathic and associated types of pulmonary arterial hypertension. Pulm. Circ., 5 (4): 640-8, 2015.

5- HUERTAS A., TU L., GAMBARYAN N., GIRERD B., PERROS F., MONTANI D., et al.: Leptin and regulatory T-lymphocytes in idiopathic pulmonary arterial hypertension. Eur. Respir. J., 40: 895-904, 2012.

6- MEDOFF B.D.: Fat, fire and muscle the role of adiponectin in pulmonary vascular inflammation and remodeling. Pulm Pharmacol Ther., 26 (4): 420-6, 2013.

7- WENG M., RAHER M.J., LEYTON P., COMBS T.P., SCHERER P.E., BLOCH K.D., et al.: Adiponectin decreases pulmonary arterial remodeling in murine models of pulmonary hypertension. Am. J. Respir. Cell. Mol. Biol., Vol 45. pp. 340-347, 2011.

8- ZHANG H., GONG Y., WANG Z., JIANG L., CHEN R., FAN X., et al.: Apelin inhibits the proliferation and migration of rat PASMCs via the activation of PI3K/ Akt/mTORsignal and the inhibition of autophagy under hypoxia. J. Cell. Mol. Med., 18 (3): 542-53, 2014.

9- JASIEWICZ M., KNAPP M., WASZKIEWICZ E., PTASZYNSKA-KOPCZYNSKA K., SZPAKOWICZ A., SOBKOWICZ B., et al.: Enhanced IL-6 trans-signaling in pulmonary arterial hypertension and its potential role in disease-related systemic damage. Cytokine, 76 (2): 187-92. 9, 2015.

10- SELIM S.: Frequency and pattern of chronic complications of diabetes and their association with glycemic control. Diabetes Metab Syndr. 11 (Suppl 1): S311-S314, 2017.

11- EDIC. Diabetes Control and Complications Trial/Epidemiology of Diabetes Interventions and Complications Study Research Group, "Long-term effect of diabetes and its treatment on cognitive function," The New England Journal of Medicine, Vol. 356, No. 18, pp. 1842-1852, 2007.

12- MCAULEY K., WILLIAMS S., MANN J., WALKER R., LEWIS-BARNED N., TEMPLE L., et al.: Diagnosing insulin resistance in the general population. Diabetes Care, 24: 460-464, 2001.

13- YAN Z., LIU Y. and HUANG H.: Association of glycosylated hemoglobin level with lipid ratio and individual lipids in type 2 diabetic patients. Asian. Pac. J. Trop. Med., 5 (6): 469-71, 2012.

14- ANNADURAI T., VASANTHAKUMAR A., GERALDINE P. and THOMAS P.A.: Variations in erythrocyte antioxidant levels and lipid peroxidation status and in serum lipid profileparameters in relation to blood haemo- globin A1c values in individuals with type 2 diabetes mellitus. Diabetes. Res. Clin. Pract., 105 (1): 58-69, 2014.

15- CHAWLA A., CHAWLA R. and JAGGI S.: Microvascular and macrovascular complications in diabetes mellitus: Distinct or continuum? Indian. J. Endocrinol. Metab., 20 (4): 546-51, 2016.

16- CHEN J., JIN J., SONG M., DONG H., ZHAO G. and HUANG L.: C-reactive protein downregulates endothelial nitric oxide synthase expression and promote apoptosis in endothelial progenitor cells through receptor for advanced glycation end-products. Gene., 1, 496 (2): 12835, 2012.

17- PUGH M.E. and HEMNES A.R.: Metabolic and hormonal derangements in pulmonary hypertension: From mouse to man. Int. J. Clin. Pract. Suppl., 168: 5-13, 2010.

18- JAYASHREE B., BIBIN Y.S., PRABHU D., SHANTHIRANI C.S., GOKULAKRISHNAN K., LAKSHMI B.S., et al.: Increased circulatory levels of lipopolysaccharide (LPS) and zonulin signify novel biomarkers of proinflammation in patients with type 2 diabetes. Mol. Cell. Biochem., 388 (1-2): 203-10, 2014.

19- KOUSATHANA F., GEORGITSI M., LAMBADIARI V., GIAMARELLOS-BOURBOULIS EJ, DIMITRIADIS G and MOUKTAROUDI M.: Defective production of interleukin 1 beta in patients with type 2 diabetes mellitus: Restoration by proper glycemic control. Cytokine, 90 : 177-184, 2017.

20- OTSUKA A., AZUMA K., IESAKI T., SATO F., HIROSE T., SHIMIZU T., et al.: Temporary hyperglycaemia provokes monocyte adhesion to endothelial cells in rat thoracic aorta. Diabetologia, 48: 2667-74, 2005.

21- PRINS K.W., ARCHER S.L., PRITZKER M., ROSE L., WEIR E.K., SHARMA A., et al.: Interleukin-6 is independently associated with right ventricular function in pulmonary arterial hypertension. J. Heart. Lung. Transplant, 37 (3): 376-384, 2018.

22- SOON E., HOLMES A.M., TREACY C.M., DOUGHTY N.J., SOUTHGATE L., MACHADO R.D., et al.: Elevated levels of inflammatory cytokines predict survival in idiopathic and familial pulmonary arterial hypertension. Circulation, 31, 122 (9): 920-7, 2010.

23- OZATA M., GUNGOR D., TURAN M., OZISIK G., BINGOL N., OZGURTAS T., et al.: Improved glycemic control increases fasting plasma acylation stimulating Protein and decreasesleptin concentrations in type II diabetic subjects. J. Clin. Endocrinol. Metab., 86 (8): 3659-64, 2001.

24- HUERTAS A., TU L., THUILLET R., LE HIRESS M., PHAN C., RICARD N., et al.: Leptin signalling system as a target for pulmonary arterial hypertension therapy. Eur. Respir. J., 45 (4): 1066-80, 2015.

25- SCHAFER K., HALLE M., GOESCHEN C., DELLAS C., PYNN M., LOSKUTOFF D.J., et al.: Leptin promotes vascular remodeling and neointimal growth in mice. Arterioscler. Thromb. Vasc. Biol., 24: 112-117, 2004.

26- LI L., YANG G., LI Q., TANG Y., YANG M., YANG H., et al.: Changes and relations of circulating visfatin, apelin, and resistin levels in normal, impaired glucose tolerance, and type 2 diabetic subjects. Exp. Clin. Endocrinol. Diabetes, 114 (10): 544-8, 2006. 
27- DRAY C., DEBARD C., JAGER J. DISSE E, DAVIAUD D, MARTIN P., et al.: Apelin and APJ regulation in adipose tissue and skeletal muscle of type 2 diabetic mice and humans. American Journal of Physiology-Endocrinology and metabolism, 298, E1161-E1169, 2010.

28- CHANDRA S.M., RAZAVI H., KIM J., AGRAWAL R., KUNDU R.K., DE JESUS PEREZ V., et al.: Disruption of the apelin-APJ system worsens hypoxia-induced pulmonary hypertension. Arterioscler Thromb. Vasc. Biol., 31 (4): 814-20, 2011.

29- ANDERSEN C.U., MARKVARDSEN L.H., HILBERG O. and SIMONSEN U.: Pulmonary apelin levels and effects in rats with hypoxic pulmonary hypertension. Respir. Med., 103: 1663- 1671, 2009.

30- ZHANG H., CHU J., SHEN T., YANG C., HUANG X., WANG S., WANG X. and LI J.: Apelin ameliorates myocardial insulin resistance and improves myocardial injury in diabetes. J. Am. Coll. Cardiol., 66: 20, 2015.

31- HABCHI M., DUVILLARD L., COTTET V., BRINDISI M.C., BOUILLET B., BEACCO M., et al.: Circulating apelin is increased in patients with type 1 or type 2diabetes and is associated with better glycaemic control. Clin. Endocrinol. (Oxf), 81 (5): 696-701, 2014.

32- KIM J.: Apelin-APJ signaling: A potential therapeutic target for pulmonary arterial hypertension. Mol. Cells, 37 (3): 196-201, 2014.

33- SANTOVITO D., De NARDIS V., MARCANTONIO P., MANDOLINI C., PAGANELLI C., VITALE E., et al.: Plasma exosome microRNA profiling unravels a new potential modulator of adiponectin pathway in diabetes:
Effect of glycemic control. J. Clin. Endocrinol. Metab. 99 (9): E1681-5. 1671, 2014.

34- GAO H., FALL T., VAN DAM R.M., FLYVBJERG A., ZETHELIUS B., INGELSSON E., et al.: Evidence of a causal relationship between adiponectin levels and insulin sensitivity: A Mendelian randomization study. Diabetes, 62 (4): 1338-44, 2013.

35- HANSMANN G., WAGNER R.A., SCHELLONG S., PEREZ V.A., URASHIMA T., WANG L., et al.: Pulmonary arterial hypertension is linked to insulin resistance and reversed by peroxisome proliferator-activated receptorgamma activation. Circulation, 115 (10): 1275-84, 2007.

36- DURRANI S., SHAH J., KHAN M.A. and JAN M.R.: Relationship of Adiponectin level with lipid profile in Type-2 diabetic men with coronary heart disease. J. Ayub. Med. Coll. Abbottabad, 27 (1): 32-5, 2015.

37- RICHTER M.J., MILGER K., HAASE S., SOMMER N., TELLO K., SEEGER W., et al.: The clinical significance of HbA1c in operable chronic thromboembolic Pulmonary Hypertension. PLoS One, 11 (3): e0152580, 2016.

38- BELLY M.J., TIEDE H., MORTY R.E., SCHULZ R., VOSWINCKEL R., TANISLAV C., et al.: "HbA 1c in pulmonary arterial hypertension: A marker of prognostic relevance?" Journal of Heart and Lung Transplantation. vol. 31, no., 10: pp. 1109-1114, 2012.

39- GRINNAN D., FARR G., FOX A. and SWEENEY L.: The Role of Hyperglycemia and insulin Resistance in The Development and Progression of Pulmonary Arterial Hypertension. J. Diabetes. Res., 2481659, 2016.

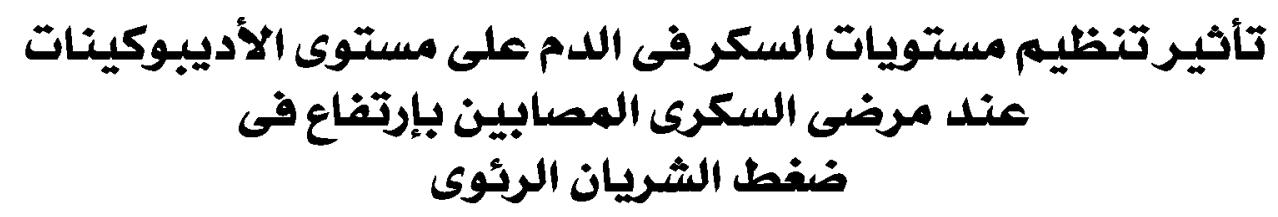

أظهرت الدراسات الحديثة دور مرض السكرى فى إرتفاع ضغط الدم الرئوى. كما أن العديد من الأدييوكينات والتى تعتبر دلالات دقيقة

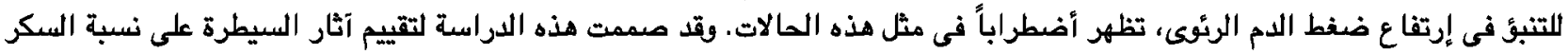

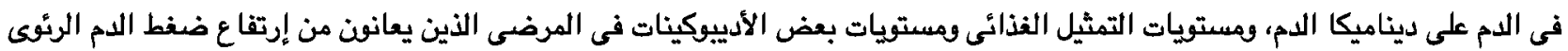

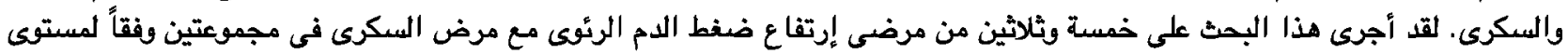

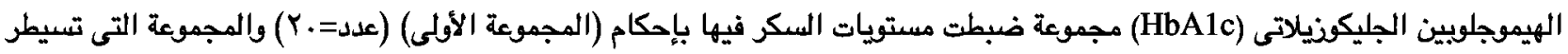

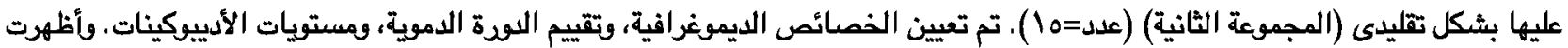

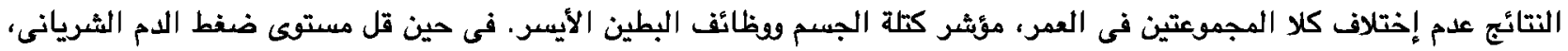

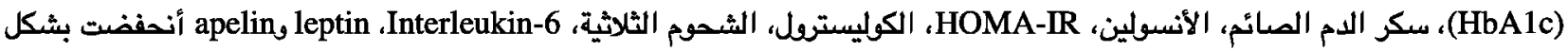

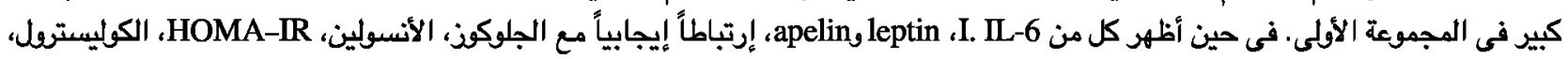
في كلا المجموعتين. و لذا فإن السيطرة الجيدة على نسبة السكر فى الدم لها تأثير على ديناميكا الدم والنمط الأيضى والألتهابى

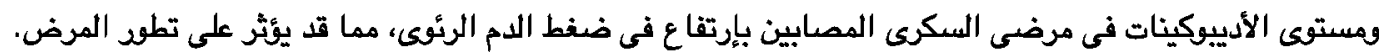

